\title{
A novel loop-mediated isothermal amplification-based test for detecting Neospora caninum DNA
}

\author{
Andrea Estefanía Ramos ${ }^{1 \dagger}$, Marina Muñoz ${ }^{1 \dagger}$, Jesús Alfredo Cortés-Vecino ${ }^{2}$, Paola Barato ${ }^{3}$ \\ and Manuel Alfonso Patarroyo ${ }^{1,4^{*}}$
}

\begin{abstract}
Background: Neospora caninum is a cyst-forming, coccidian parasite which is known to cause neurological disorders in dogs and abortion and neonatal mortality in cows and other livestock. This study reports the development of a loop-mediated isothermal amplification (LAMP) assay based on the Neospora caninum Nc-5 gene and compares its efficacy for detecting DNA to that of a semi-nested PCR test.

Results: Six primers were designed based on the Nc-5 repeat region of N. caninum. Specific LAMP primers led to successful amplification of $\mathrm{N}$. caninum DNA at $63^{\circ} \mathrm{C}$ in 30 min. The LAMP assay was highly specific (i.e. it did not reveal cross-reactivity with other parasite species) and had a low N. caninum plasmid DNA limit of detection (1 fg), which is ten times higher than that for the semi-nested PCR. LAMP applicability was evaluated using a set of naturally-infected samples (59 from canine faeces and five from bovine abortions). Thirty-nine percent (25/64) of the naturally-infected samples were positive for N. caninum DNA by LAMP and 36\% (23/64) by semi-nested PCR. However, the LAMP assay is much faster to perform than semi-nested PCR and provides results in $30 \mathrm{~min}$.

Conclusion: The optimized reaction conditions described in this study resulted in a sensitive, specific and rapid technique for detecting N. caninum DNA. Considering the advantages of LAMP for detecting N. caninum DNA, further assays aimed at testing its usefulness on a wider range of field samples are recommended.
\end{abstract}

Keywords: Neospora caninum, Neosporosis, Loop-mediated isothermal amplification, Semi-nested PCR, Nc-5 gene

\section{Background}

Neospora caninum is an obligate intracellular tissue protozoan parasite belonging to the Phylum Apicomplexa (subclass: Coccidia) [1]. The infectious disease caused by this parasite is called neosporosis and is mainly associated with severe neuromuscular disease in dogs and other canids (considered definitive host) and abortion in cows (the main intermediate host) and other livestock [2-6], causing major economic losses for livestock farmers [7]. The role of domestic dogs and other canids is essential for the life-cycle's continuity due to

\footnotetext{
* Correspondence: mapatarr.fidic@gmail.com

${ }^{\dagger}$ Equal contributors

'Molecular Biology and Immunology Department, Fundación Instituto de Inmunología de Colombia, Bogotá, Colombia

${ }^{4}$ School of Medicine and Health Sciences, Universidad del Rosario, Bogotá, Colombia

Full list of author information is available at the end of the article
}

the excretion of environment-resistant oocysts, this being the only form of horizontal transmission in herbivores [8]. The other way of acquiring the infection is by consuming oocysts from aborted tissue (exogenous origin) or during the birth of a persistently-infected individual (endogenous origin) [7].

The most common techniques for diagnosing $N$. caninum are those aimed at detecting specific antibodies in sera; different assays have been developed including the indirect fluorescent antibody test (IFAT), various enzyme-linked immunosorbent assays (ELISA), immunoblotting (IB) and direct agglutination tests (DAT) $[9,10]$. The advantage of serological tests is that they provide information regarding infection stage [11]; however, specific antibodies' fluctuation during infection limits serological methods because such fluctuation sometimes comes below serological tests' detection 
limits [12]. Immunohistochemical staining was one of the first techniques used for diagnosing $N$. caninum infection; this technique is often used for demonstrating the parasite's presence in lesions, particularly in the brain and heart [13]. Nevertheless, immunohistochemistry techniques have been shown to have relatively low sensitivity, and this may be related to low parasite number and the degree of autolysis in analyzed tissues [10]. Regarding molecular diagnosis of infection, polymerase chain reaction (PCR)-based tests have the advantage of being able to amplify small amounts of parasite DNA in different types of biological samples and are directed towards amplifying different genes, the $N$. caninum $N c-5$ repeat sequence and internal transcribed spacer (ITS1) being most frequently used [14]. Different PCR formats have been developed recently for increasing sensitivity in detecting $N$. caninum DNA, i.e. nested, semi-nested, and real-time PCR [9]. However, PCR diagnosis implies the use of sophisticated equipment such as a thermocycler for amplifying nucleic acids, as well as requiring personnel trained in such area and additional time for detecting the amplified products [15].

Since loop-mediated isothermal amplification (LAMP) was introduced in 2000, this technique has represented a cost-effective alternative for molecular diagnosis [16]. LAMP allows the amplification of nucleic acids; it provides high specificity, sensitivity, and rapidity in isothermal conditions and is based on the strand displacement reaction principle and the formation of loop structures amplifying a sequence of interest. This involves using a polymerase having strand displacement activity and six primers specifically recognising eight different regions in the target sequence [17].

Unlike conventional PCR, LAMP is carried out in isothermal conditions between 60 and $65{ }^{\circ} \mathrm{C}$, thereby eliminating the need for using a thermocycler. LAMP has been widely used in detecting infections caused by different microorganisms, including those caused by protozoan parasites such as Toxoplasma gondii [18-20], Trypanosoma spp. [21], Theileria annulata [22], Babesia caballi [23] and Leishmania spp. [24, 25]. This work was thus aimed at describing the development of a LAMPtype test for detecting $N$. caninum infection and comparing its detection limit to that of the previouslyreported semi-nested PCR detection method [26].

\section{Methods}

\section{Designing primers}

Six primers were designed based on the single $N$. caninum Nc-5 repeat region (GenBank: AY459289.1) using LAMP primer design software (Primer Explorer V4) (https://primerexplorer.jp/e/). The two outer primers, called forward (F3) and backward (B3), allow strand displacement; the inner primers, forward inner (FIP) and backward inner primers (BIP), have two types of sequences: the sense and antisense sequences of the region to be amplified. One is for priming during the noncyclic step and the other for self-priming during cyclic amplification. FIP contains the F1C region (complementary to the F1 region) and the F2 region; BIP contains the $\mathrm{B} 1 \mathrm{C}$ sequence (complementary to $\mathrm{B} 1$ ) and the $\mathrm{B} 2$ sequence [17]. The design of loop primers (FLP and BLP) is also included for accelerating the reaction and reducing amplification time [27]. The loop primers correspond to regions between $\mathrm{F} 1$ and $\mathrm{F} 2$ and $\mathrm{B} 1$ and $\mathrm{B} 2$.

LAMP test selectivity was determined by in silico analysis using $N c-5$ gene DNA sequences from different isolates, taking the information currently available in databases into account. Homologous sequences were determined using the BLAST tool which is available on the National Center for Biotechnology Information (NCBI) page, taking the sequence for the $\mathrm{Nc}-5$ gene used for designing the primers as the query sequence.

\section{Preparing plasmid DNA}

A 350 base pair (bp) fragment from the $N c-5$ region was amplified from $N$. caninum Bahía strain total DNA using high fidelity KAPA HiFi HotStart DNA polymerase (KAPA Biosystems, Woburn, MA, USA) and a previously reported set of primers: Np21+ (5'-CCC AGT GCG TCC AAT CCT GTA AC-3') / Np6+ (5'-CTC GCC AGT CAA CCT ACG TCT TCT-3') [28]. The amplified product was ligated into the pGEM-T easy vector (Promega, Madison, WI, USA) multiple cloning site and then used for transforming E. coli JM109 competent cells (Promega), following the manufacturer's recommendations. Extracted plasmid DNA was confirmed by sequencing and used as amplification template in all LAMP standardization assays.

\section{LAMP reaction}

Bst 2.0 DNA Polymerase (New England Biolabs, Herts, UK), having strand displacement activity, was used for LAMP assay amplification at $25 \mu \mathrm{l}$ final reaction volume. Optimization of LAMP assay conditions was carried out through evaluation of reagents concentrations following ranges reported in the literature for pathogen detection $[29,30]$ and the manufacturer's instructions. During this optimization process different concentrations from 1 to $1.6 \mathrm{M}$ of betaine (Sigma-Aldrich, St. Louis, MO, USA), $1.4 \mathrm{mM}$ to $2.8 \mathrm{mM}$ of dNTP's (Bioline, UK) and from 4 to $8 \mathrm{mM} \mathrm{MgSO}_{4}$ [31] were tested in PCR master mix. Various amounts of primers ( 3 and 5 pmol F3 and B3; 30 and 40 pmol FIP and BIP; and 5, 10, and 15 pmol FLP and BLP) were used for identifying the best conditions. The reaction mixture was incubated at $61{ }^{\circ} \mathrm{C}, 63^{\circ}$ $\mathrm{C}$ or $65{ }^{\circ} \mathrm{C}$ for 40,50 or $60 \mathrm{~min}$, for determining optimum LAMP assay temperature and incubation time. 
The reaction was stopped by heating at $80{ }^{\circ} \mathrm{C}$ for $10 \mathrm{~min}$, according to the manufacturer's recommendations. The best reaction conditions were defined as those where the generation of the stem-loop structure into LAMP mixture allow the production of an amplification pattern of high quality (defined bands inter-spaciads, ladder-like banding) [32]. The optimal reaction mix was established as follows: $1 \times$ isothermal amplification buffer $\left(20 \mathrm{mM}\right.$ Tris- $\mathrm{HCl}, 50 \mathrm{mM} \mathrm{KCl}, 10 \mathrm{mM}\left(\mathrm{NH}_{4}\right)_{2} \mathrm{SO}_{4}$, $2 \mathrm{mM} \mathrm{MgSO}_{4}, 0.1 \%$ Tween-20), $2.8 \mathrm{mM}$ of each dNTP, 1.6 $\mathrm{M}$ betaine (Sigma-Aldrich), $8 \mathrm{U}$ Bst DNA polymerase and $1 \mathrm{ng}$ of plasmid DNA. All reagents and samples were mixed on ice. An additional reaction with molecular grade water instead of template DNA was included as a negative control due to the LAMP reaction's high sensitivity in each run, and the following precautions were taken: manipulating the reaction tubes was minimised, and the LAMP assay's different steps were carried out in separated environments to prevent crosscontamination. The amplification products were submitted to agarose gel electrophoresis analysis using $2 \%$ agarose and stained with SYBRsafe (Invitrogen Corp., California, CA, USA) in an independent area.

\section{LAMP analytical performance}

Three different assays were used for evaluating LAMP test analytical performance. DNA from 5 closely-related protozoan parasites (Sarcocystis cruzi, Sarcocystis hominis, Hammondia hammondi, Toxoplasma gondii and Cryptosporidium parvum) was used as a template for evaluating LAMP test selectivity. Sarcocystis cruzi, S. hominis and $H$. hammondi DNA controls were kindly donated by the United States Department of Agriculture (USDA, Beltsville). Toxoplasma gondii DNA came from the ME49 strain (clonal type II), cat 19, collected during June 2014, donated by Professor Jitender Dubey (USDA, Beltsville) and the C. parvum control was bought from the University of Texas. Two different concentrations were used as a template when evaluating independent reactions for each species: direct DNA extraction and at 1:10 concentration (i.e. 20-40 ng, the range equivalent to the amount of DNA used for any PCR assay) [33]. Two $\mu \mathrm{l}$ of DNA from each species at the following concentrations: $19 \mathrm{ng} / \mu \mathrm{l}$ S. cruzi, $10 \mathrm{ng} / \mu \mathrm{l}$ S. hominis, $175 \mathrm{ng} / \mu \mathrm{l} \mathrm{H}$. hammondi, $11 \mathrm{ng} / \mu \mathrm{l}$ T. gondii and $90 \mathrm{ng} / \mu \mathrm{l}$ C. parvum were used as template in the initial test. The second verification step involved extracting DNA from healthy domestic dogs' faecal samples and fetal brain tissue negative for Neospora. Such DNA was used for evaluating the absence of primer cross-reactivity with hosts' DNA. A third verification step involved evaluating the sequence of LAMP products digested with the MspI restriction enzyme ( $16 \mathrm{~h}$ incubation at $\left.37^{\circ} \mathrm{C}\right)$, according to the manufacturer's instructions. The resulting fragments were analyzed by electrophoresis. The $M s p \mathrm{I}$ enzyme has a recognition site in the region between B1C and B2 (Fig. 1a), meaning that it would be expected that 218 and $132 \mathrm{bp}$ fragments would be obtained after treating the product resulting from LAMP amplification.

The limit of detection (LoD) was determined following the methodology reported earlier for LAMP tests [34, 35]. Serial 10-fold plasmid DNA dilutions (ranging from $1 \times 10^{-1}$ to $1 \times 10^{-6} \mathrm{ng}$ ) were made in $\mathrm{H}_{2} \mathrm{O}$. LAMP assay LoD was compared to that for semi-nested PCR. Each assay was done in triplicate and incubated at $63{ }^{\circ} \mathrm{C}$ for $30 \mathrm{~min}$. Semi-nested PCR assays were carried out using previously reported primers [26]. All PCR reactions were performed in a $10 \mu \mathrm{l}$ volume containing: $1 \times \mathrm{NH}_{4}$ reaction buffer, $0.5 \mu \mathrm{M}$ each primer, $2.5 \mathrm{mM} \mathrm{MgCl} 2,0.2 \mathrm{mM}$ each dNTP and $0.5 \mathrm{U}$ Biolase DNA polymerase (Bioline). The first amplification round followed the originally reported conditions [26]; the second involved using a microliter of first PCR product for amplification with the internal semi-nested primers in the following conditions: $95{ }^{\circ} \mathrm{C}$ for $5 \mathrm{~min}$ and then 35 cycles at $95{ }^{\circ} \mathrm{C}$ for $15 \mathrm{~s}, 54{ }^{\circ} \mathrm{C}$ for $30 \mathrm{~s}, 72{ }^{\circ} \mathrm{C}$ for $1 \mathrm{~min}$, followed by a final extension step at $72{ }^{\circ} \mathrm{C}$ for $10 \mathrm{~min}$. An aliquot of each PCR product was examined on $2 \%$ agarose gel stained with SYBRsafe.

The analytical performance of both tests was also evaluated directly using $N$. caninum genomic DNA (NC-1 strain); LoD was determined using 10-fold serial dilutions ranging from $1 \times 10^{-1}(0.5 \mathrm{ng} / \mu \mathrm{l})$ to $1 \times 10^{-6}(5 \mathrm{fg} /$ $\mu \mathrm{l})$ subjected to amplification in the conditions mentioned above.

\section{LAMP assay for $N$. caninum with clinical samples}

A set of 64 samples was used for evaluating the LAMP method regarding $N$. caninum detection. The set consisted of 3 brain samples from bovine abortions, 2 samples from the pool of bovine abortion tissue (lungs, heart, liver and spleen) and 59 samples of canine faeces (taken from around cattle herds having a history of abortion). The pool of bovine abortion tissue came from abortions of cows positive for N. caninum by IFA. Such tissue was evaluated by histopathology; this led to lesions compatible with neosporosis being identified. A Wizard Genomic DNA Purification Kit (Promega) was used for extracting DNA from clinical abortion tissue samples and a Stool DNA Isolation Kit (Norgen Biotek Corp., Thorold, ON, Canada) for extracting DNA from samples of faeces, following the manufacturers' instructions in both cases. The 64 samples were used for $N$. caninum infection identification, using both the LAMP method and the previously-described semi-nested PCR method [26]. Both molecular assays were carried out independently in double-blind experiments; their results were reported regarding $N$. caninum infection frequency. 


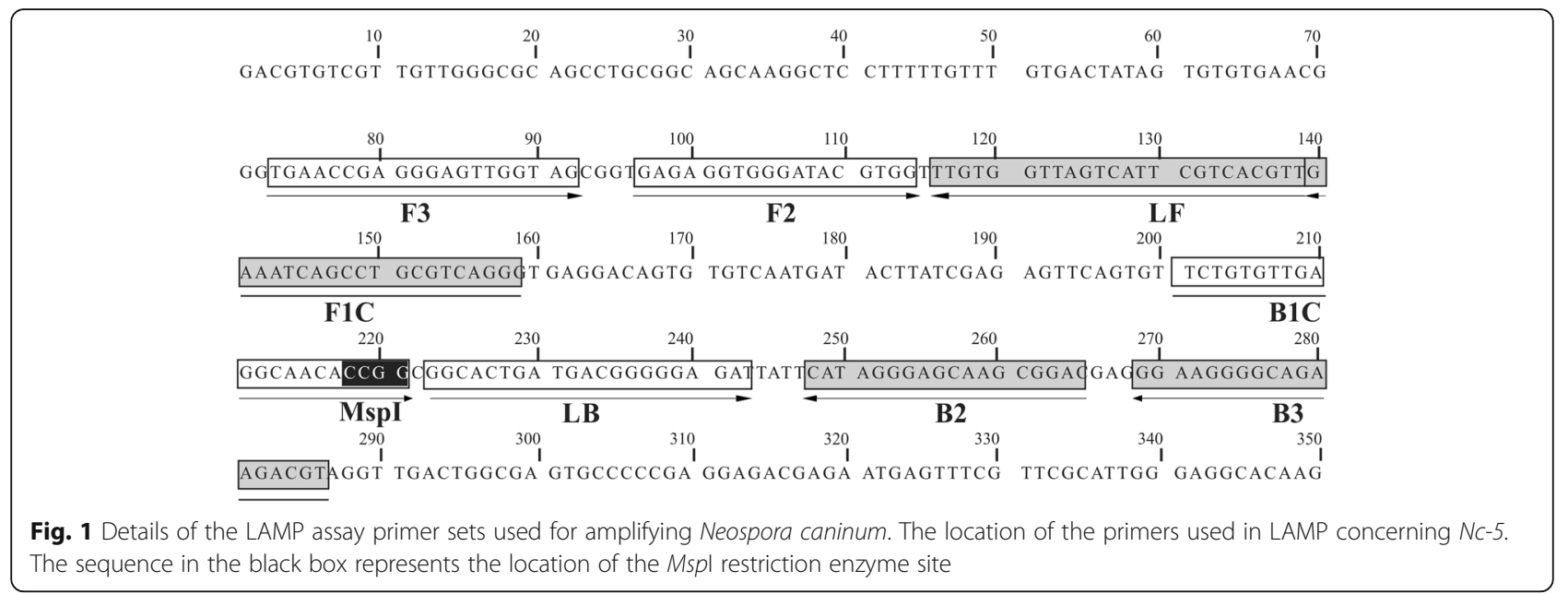

Agreement between both molecular assays regarding $N$. caninum DNA detection was evaluated as an indicator of LAMP method performance, using the kappa (к) соefficient. All results were reported along with their 95\% confidence intervals (95\% CI) which were calculated using the bootstrap method. Stata 10 software was used for statistical analysis.

\section{Results}

\section{Selection of designed primers}

Table 1 provides primer sequences and Fig. 1 their location in the $N c-5$ sequence. LAMP test selectivity was evaluated by in silico analysis, comparing reported sequences. Eighty-three $N c-5$ gene sequences from different isolates were recovered from databases and aligned to check how conserved the primers designed for the LAMP method were; 38 sequences were excluded from further analysis as they did not have the required length for bioinformatics analysis (i.e. they did not cover Nc-F3 and Nc-B3 primers' annealing sites). A further group of 9 sequences was excluded as lacking clinical relevance, since the host from which they came did not play a relevant role in $N$. caninum's biological cycle and thus isolates infecting these species lacked epidemiological interest, leaving 36 sequences to be analyzed (information regarding all the sequences found and describes the exclusion scheme is provided in Additional file 1: Table S1).

Multiple sequence comparison by log-expectation (MUSCLE) [36] was used for comparing the set of sequences selected for analysis; the sequences' overall identity was $84.72 \%$. Regarding the primers' annealing sites, 90.0 and $100 \%$ identity, respectively, was found at the F3 and B3 primer annealing sites. Differences in primer F3 annealing site were only observed in 4 sequences which had two varying positions. Additional file 2: Figure S1 shows the annealing sites for all LAMP-designed primers, as well as the identity percentage for all sequences analyzed. The recognition sites for the primers designed for the LAMP method were conserved in most $N$. caninum isolates and the strains analyzed.

\section{LAMP optimization}

It was found that the optimum concentrations for the primers in the LAMP reaction were 40,5 and 15 pmol for the inner/outer/loop primers, respectively. Using specific primers for LAMP resulted in successful

Table 1 A list of primers used for the LAMP method

\begin{tabular}{|c|c|c|c|c|}
\hline Primer name & Type & Length & Localization $^{a}$ & Sequence $\left(5^{\prime}-3^{\prime}\right)$ \\
\hline F3 & Forward outer & 20 & $73-92$ & TGAACCGAGGGAGTTGGTAG \\
\hline B3 & Reverse outer & 18 & $269-286$ & ACGTCTTCTGCCCCTTCC \\
\hline \multirow[t]{2}{*}{$F P^{b}$} & Forward inner & 40 & F1C, 140-160 & ACCCTGACGCAGGCTGATTTC \\
\hline & $(F I P=F 1 C+F 2)$ & & $F 2,97-115$ & GAGAGGTGGGATACGTGGT \\
\hline \multirow[t]{2}{*}{$B I P^{b}$} & Reverse inner & 40 & B1C, 200-221 & TTCTGTGTTGAGGCAACACCGG \\
\hline & $(B I P=B 1 C+B 2)$ & & $B 2,248-265$ & GTCCGCTTGCTCCCTATG \\
\hline FLP & Forward Loop & 24 & 116-139 & AACGTGACGAATGACTAACCACAA \\
\hline BLP & Reverse Loop & 21 & $223-243$ & GGCACTGATGACGGGGGAGAT \\
\hline
\end{tabular}

a Localization of the primers is based on the nucleotide sequence of $N$. caninum Nc-5 unique repetitive region (GenBank: AY459289.1)

${ }^{b}$ Each inner primer of LAMP contains two connected primers 
amplification of $N$. caninum plasmid DNA from $61{ }^{\circ} \mathrm{C}$ to $65{ }^{\circ} \mathrm{C} ; 63{ }^{\circ} \mathrm{C}$ was selected as optimum temperature for the LAMP assay as a defined ladder-type band pattern was identified on agarose gel according to that expected for this type of experiment (detected after 40, 50 and 60 min reaction time had elapsed) (Fig. 2a). The preceding was due to the formation of a mixture of various sized stem-loop DNA and cauliflower-like structures from the alignment between the alternately inverted repeats in the target sequence in the same chain [17]. Two shorter reaction times were evaluated (20 and $30 \mathrm{~min}$ ) for determining the minimum reaction time in which $N$. caninum DNA could be amplified; it was found that a welldefined and expected ladder-type pattern was obtained after $30 \mathrm{~min}$ and thus chosen as the reaction time for the method (Fig. 2b). The assay described above provided an alternative technique for detecting $N$. caninum DNA rapidly, since including loop primers in the reaction led to reducing DNA amplification time (usually taking $60 \mathrm{~min}$ ), amplifying $1 \mathrm{ng} N$. caninum DNA at $63{ }^{\circ} \mathrm{C}$.

\section{Analysis of LAMP test performance}

LAMP test selectivity was successfully demonstrated by the absence of amplification when DNA from other related parasites (S. cruzi, S. hominis, H. hammondi, T. gondii and C. parvum) and later when DNA extracted from healthy domestic dogs' fecal samples and fetal brain tissue negative for Neospora was used as amplification template, during a $60 \mathrm{~min}$ LAMP reaction (data not shown). The amplified product restriction pattern was that to be expected following Msp I digestion (Fig. 2c). These findings confirmed the optimal performance based on the single $N c-5$ sequence in the $N$. caninum genome used in this study, thereby ensuring selectivity in amplifying this parasite's DNA.

The LoD for the products amplified in the LAMP assay (Fig. 3a) and the semi-nested PCR (Fig. 3b) was $1 \mathrm{fg}$ and $10 \mathrm{fg}$ for $N$. caninum plasmid DNA. These results were consistent when $N$. caninum genomic DNA LoD was determined directly; LAMP assay LoD was $5 \mathrm{fg}$ (Fig. 3c), while semi-nested PCR LoD was 50 fg (Fig. 3d). The assay time used for determining LoD was $30 \mathrm{~min}$.

\section{Using the LAMP assay with clinical samples}

A set of samples including 5 fetal tissues from bovine abortions and 59 samples of canine faeces was tested by LAMP and compared to the semi-nested PCR method (Table 1). N. caninum infection frequency detected by the LAMP method was $39.1 \%(n=25$; $95 \%$ CI: $27.10-52.0 \%]$, this being higher than that detected by semi-nested PCR (35.9\%) [ $n=23$; 95\% CI: $24.31-$ $48.90 \%)$. Comparative analysis of the techniques' results gave a discordant result for the 14 samples (6 were only positive for semi-nested PCR and 8 just for

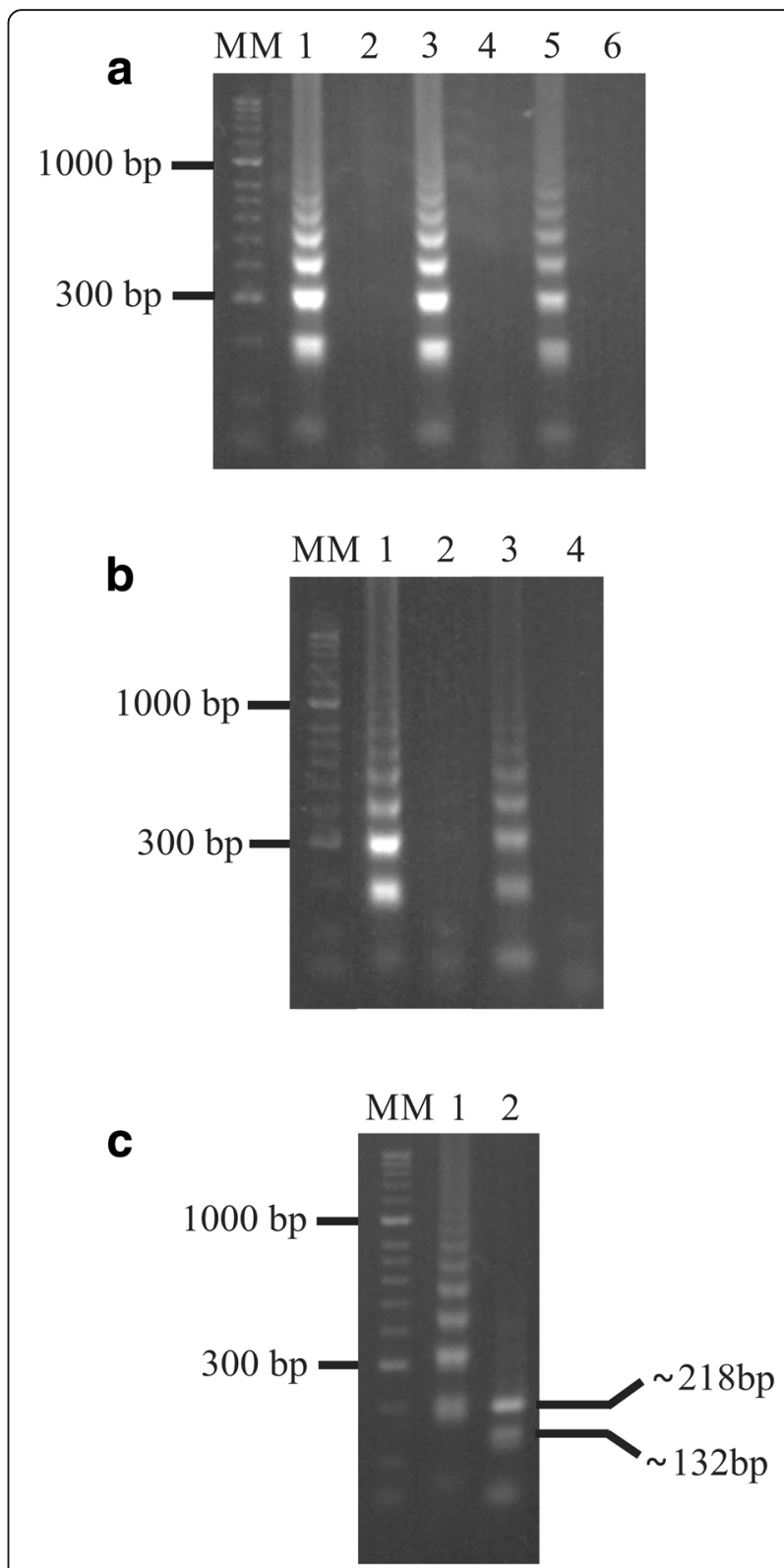

Fig. 2 Using the LAMP assay for detecting N. caninum plasmid DNA containing the Nc-5 region on a SYBRsafe stained agarose gel. a The effects of reaction time. Lanes 1 and 2: 60 min; Lanes 3 and 4: 50 min; Lanes 5 and 6: 40 min. Lanes 2, 4 and 6 represent negative controls for each reaction time. $\mathbf{b}$ Optimizing LAMP assay conditions. Lanes 1 and 2: 30 min; Lanes 3 and 4: 20 min. Lanes 2 and 4 are the negative control for each reaction time. c Restriction analysis of $\mathrm{N}$. caninum LAMP products amplified from plasmid DNA containing the Nc-5 region. The digestion products were run on a $3 \%$ agarose gel. Lane 1: N. caninum LAMP product; Lane 2: Mspl digestion of $N$. caninum product (132-218 bp bands, according to predicted size). Lane MM in $\mathbf{a}, \mathbf{b}$ and $\mathbf{c}$ is the HyperLadder II (Bioline) DNA molecular marker

the LAMP test). Overall agreement between both molecular assays was $78.13 \%$, kappa coefficient being 0.533 (95\% CI: 0.263-0.721); such estimator came 

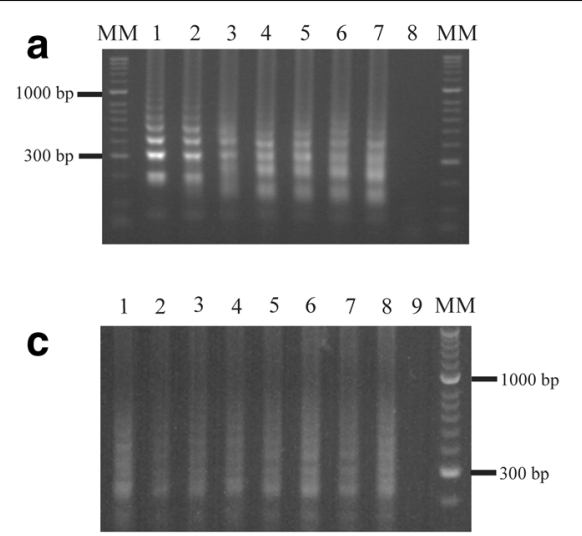
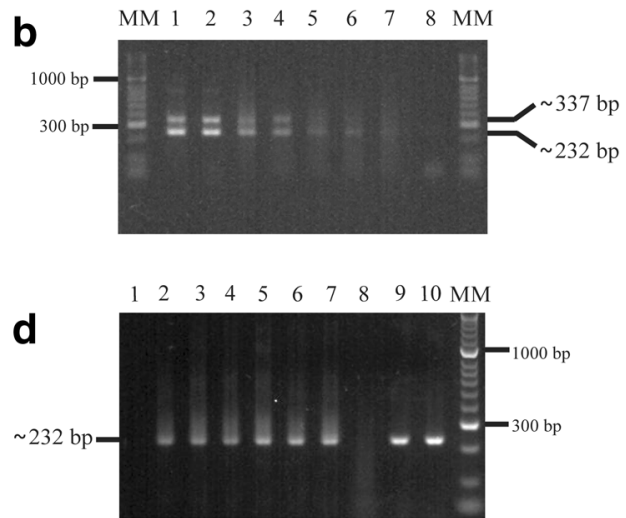

Fig. 3 LAMP and semi-nested PCR Limit of Detection (LoD). a LAMP reaction. b Semi-nested PCR. Ten-fold serial dilutions of plasmid DNA were used in both $\mathbf{a}$ and $\mathbf{b}$; they contained the Nc-5 region for detecting N. caninum by agarose gel electrophoresis analysis. From left to right: Lane MM: HyperLadder II (Bioline) DNA molecular marker; Lane 1: amplification of 1 ng plasmid DNA containing the cloned N. caninum fragment; Lanes 2-7: 10-fold serial dilutions of N. caninum plasmid DNA $\left(10^{-1}\right.$ to $\left.10^{-6} \mathrm{ng}\right)$; Lane 8: negative control without target DNA. Semi-nested PCR products showed specific amplification of $N$. caninum, having $10^{-5}$ ng LoD whereas LAMP LoD was $10^{-6}$ ng. LAMP and semi-nested PCR LoD in both $\mathbf{c}$ and $\mathbf{d}$ using serial dilutions of N.caninum genomic DNA (NC-1 strain) by visualization on an agarose gel. c LAMP reaction. Lane MM: HyperLadder II (Bioline) DNA molecular marker; Lane 1: amplification of N. caninum genomic DNA (50 ng); Lanes 2-7: 10-fold serial dilutions (10 ${ }^{-1}$ to 10 ${ }^{-6}$ ng); Lane 8: positive control (plasmid DNA); Lane 9: negative control (no DNA template). d Semi-nested PCR. Lane MM: HyperLadder II (Bioline) DNA molecular marker; Lane 1: negative control (no DNA template); Lane 2: amplification of N. caninum genomic DNA (50 ng); Lanes 3-8: 10-fold serial dilutions $\left(10^{-1}\right.$ to $\left.10^{-6} \mathrm{ng}\right)$; Lanes 9, 10: positive controls (plasmid DNA)

within the "moderate" range according to Remmerbach's classification [37].

\section{Discussion}

Despite the importance of $N$. caninum in veterinary medicine (i.e. recognized as a leading cause of infectious abortions in cattle worldwide), no fully effective vaccine or treatment is available to prevent or cure such infection [38]. The development of DNA-based methods such as conventional PCR [39, 40], nested and semi-nested PCR $[41,42]$ and different quantitative PCR types [43, 44] have contributed towards diagnosing $N$. caninum infection. However, some of these methods are timeconsuming, laborious and may require the use of specialized equipment. More recently, the LAMP technique for DNA amplification [17] has been shown to be versatile and efficient, being applied for detecting DNA from different microorganisms [45]. Nonetheless, there have been no reports regarding LAMP being used for detecting $N$. caninum. The LAMP method established in this study can detect $N$. caninum DNA in isothermal conditions at $63{ }^{\circ} \mathrm{C}$ in just $30 \mathrm{~min}$. Compared to semi-nested PCR (requiring three primers and two amplification rounds in a thermocycler, results being obtained in 2$4 \mathrm{~h}$ ), LAMP saves time, is easily carried out and requires no special equipment. It was thus proposed that the LAMP method represent a species-specific assay for detecting $N$. caninum DNA as the expected products were produced at the predicted band sizes, following LAMPamplified product digestion by restriction enzymes. The LAMP technique's specificity was due to using six primers in the reaction which recognized eight different regions in the DNA sequence of interest [27]. LAMP assay gave amplification at a 10-fold lower level, suggesting that LAMP was more sensitive than semi-nested PCR.

It was found that 25 of 64 samples $(39.1 \%)$ were positive for $N$. caninum by LAMP analysis, whereas 23 of 64 samples (35.94\%) were positive by semi-nested PCR. Even though both molecular assays revealed relatively similar infection frequencies, the LAMP method detected a slight increase in infection frequency which might have been due to the higher sensitivity reported for this method compared to that of the nested PCR [46, 47], as shown for $N$. caninum by the analytical tests described above.

Our results showed LAMP's potential use in detecting DNA in environmental samples contaminated with $N$. caninum DNA such as the faeces of infected dogs which can be attributed to oocyst excretion or the result from $N$. caninum-infected tissue ingested by dogs. The high $N$. caninum infection frequency found in samples of dog faeces agreed with other studies describing infection caused by $N$. caninum being higher in rural dogs, probably related to the availability of cattle carcasses and abortion products in such areas [48]. Despite 17 samples being positive by both techniques, there were a few discordant results regarding LAMP and semi-nested PCR (Table 1). The eight canine faeces samples positive by LAMP but negative by semi-nested PCR may have had few parasite DNA molecules below the semi-nested PCR analysis detection limit. Similar results have been described by other authors where higher sensitivity has been reported for LAMP, particularly when DNA has 
been isolated from veterinary or environmental samples $[46,49,50]$. Variation regarding DNA detection by LAMP has been reported when comparing different kits' performance when using faecal samples [51]. It should be noted that the high LAMP sensitivity level could lead to non-specific amplification [52]; it has been reported that is better to assess DNA amplification by the naked eye using hydroxynaphthol blue (HNB) or calcein (due to precipitate generation) [32], rather than by gel electrophoresis, thus avoiding the tube to be opened after the reaction has been completed [53]. On the other hand, it has been described that using impure DNA or partially purified DNA as the template could inhibit or affect LAMP amplification [54]. It has thus been suggested that an ideal LAMP detection format would thus include a closed amplification and detection unit to limit contamination [55]. It is recommended to mix reagents and sample on ice to avoid amplification artefacts that can be generated by the polymerase when incubation at a suboptimal temperature (below $45{ }^{\circ} \mathrm{C}$ ) occurs, as well as keeping the time taken for master mix preparation by less than 30 min [56].

Regarding bovine samples, LAMP detected DNA in tissue samples taken from aborted bovine fetuses from farms having a history of bovine abortion and the presence of dogs. Molecular diagnosis was positive in all cases by both amplification techniques; it is worth stressing that dogs play a main role in $N$. caninum epidemiology because they act as definitive hosts, shedding oocysts in the environment [57], this being a major risk factor for $N$. caninum-associated miscarriages and stillbirths in cattle [58-60]. Nonetheless, this assay's reliability should be further evaluated through large-scale sampling using clinical samples taken from cows, particularly from herds having a background of abortion or in groups of pregnant cattle and thus ascertain the LAMP method's ability to detect $N$. caninum DNA.

\section{Conclusion}

A LAMP assay was developed in this study for detecting $N$. caninum DNA based on the parasite's Nc-5 gene; the method's applicability was also evaluated in naturally infected samples. The optimized reaction protocol and conditions described in this study led to a LAMP technique for detecting $N$. caninum DNA, as well as providing a significant contribution; this is the first study reporting $N$. caninum DNA detection by molecular techniques in Colombia. The present LAMP method shows great promise and good prospects regarding its application in fields such as $N$. caninum prevalence monitoring and clinical diagnosis. Future work on validating the method will involve replicating tests to assess the detection limit in different biological samples to determine test performance/reliability in the field.

\section{Additional files}

Additional file 1: Table S1. LAMP test selectivity by in silico analysis using Nc-5 gene DNA. This file provides information regarding all the sequences found of $\mathrm{Nc}-5$ gene from different isolates available in databases. (XLSX 16 kb)

Additional file 2: Figure S1. Target region ( $N$. caninum Nc-5 gene) nucleotide sequence alignment. The annealing site of primers designed for LAMP is shown on the sequences of strains and isolates reported in the GenBank database, as well as percentage identity. (TIFF $12060 \mathrm{~kb}$ )

\section{Abbreviations}

95\% Cl: 95\% confidence interval; BLAST: Basic local alignment search tool; LAMP: Loop-mediated isothermal amplification; PCR: Polymerase chain reaction

\section{Acknowledgements}

We would like to thank the Universidad de Salamanca's Tropical Disease Research Centre, particularly Dr. Pedro Fernández-Soto for providing technical support, the Haematozoa Control and Biology Laboratory (Universidad Federal de Viçosa), led by Dr. Joaquín Patarroyo, for supplying the N. caninum DNA. We would like to thank the Universidad del Rosario's Microbiological Research Groupo (GIMUR) for providing some of the DNA used for the selectivity trials. We would also like to thank Dr. Mónica Santín Durán, Dr. Benjamin Rosenthal and Dr. Jitender Dubey from the United States Department of Agriculture Agricultural Research Service (USDA - ARS) for donating the Sarcocystis cruzi, Sarcocystis hominis and Hammondia hammondi genomic DNA. We would like to express our thanks to Jason Garry for translating the manuscript.

\section{Funding}

No specific funding was received to carry out this investigation.

Availability of data and materials

All the important information regarding the manuscript is available in the main text.

\section{Authors' contributions}

AER and MM carried out the experiments. AER, MM, JACV, PB and MAP designed the experiments, analyzed data and wrote the manuscript. PB and JACV provided the samples. MAP coordinated the study. All authors read and approved the final manuscript.

Ethics approval and consent to participate

Not applicable.

Consent for publication

Not applicable.

\section{Competing interests}

The authors declare that they have no competing interests.

\section{Publisher's Note}

Springer Nature remains neutral with regard to jurisdictional claims in published maps and institutional affiliations.

\section{Author details}

${ }^{1}$ Molecular Biology and Immunology Department, Fundación Instituto de Inmunología de Colombia, Bogotá, Colombia. ${ }^{2}$ Veterinary Medicine and Zootech Faculty, Universidad Nacional de Colombia, Bogotá, Colombia. ${ }^{3}$ Corporación Patología Veterinaria (Corpavet), Bogotá, Colombia. ${ }^{4}$ School of Medicine and Health Sciences, Universidad del Rosario, Bogotá, Colombia.

Received: 9 August 2017 Accepted: 21 November 2017

Published online: 29 November 2017

\section{References}

1. Dubey JP, Carpenter JL, Speer CA, Topper MJ, Uggla A. Newly recognized fatal protozoan disease of dogs. J Am Vet Med Assoc. 1988;192(9):1269-85. 
2. Dubey JP, Lindsay DS. A review of Neospora caninum and neosporosis. Vet Parasitol. 1996;67(1-2):1-59.

3. Dubey JP. Review of Neospora caninum and neosporosis in animals. Korean J Parasitol. 2003;41(1):1-16.

4. Dubey JP, Schares G. Neosporosis in animals - the last five years. Vet Parasitol. 2011;180(1-2):90-108.

5. Almeria S, Lopez-Gatius F. Bovine neosporosis: clinical and practical aspects. Res Vet Sci. 2013;95(2):303-9.

6. Sinnott FA, Monte LG, Collares TF, Silveira RM, Borsuk S. Review on the immunological and molecular diagnosis of neosporosis (years 2011-2016). Vet Parasitol. 2017;239:19-25.

7. Donahoe SL, Lindsay SA, Krockenberger M, Phalen D, Slapeta J. A review of neosporosis and pathologic findings of Neospora caninum infection in wildlife. Int J Parasitol Parasites Wildl. 2015;4(2):216-38.

8. Almeria S. Neospora caninum and wildlife. ISRN Parasitol. 2013;2013:1-23.

9. de Waal T. Advances in diagnosis of protozoan diseases. Vet Parasitol. 2012; 189(1):65-74.

10. Ortega-Mora L, Fernández-García A, Gómez-Bautista M. Diagnosis of bovine neosporosis: recent advances and perspectives. Acta Parasitol. 2006;51(1):1-14.

11. Bjorkman C, Naslund K, Stenlund S, Maley SW, Buxton D, Uggla A. An IgG avidity ELISA to discriminate between recent and chronic Neospora caninum infection. J Vet Diagn Investig. 1999;11(1):41-4.

12. Alvarez-Garcia G, Collantes-Fernandez E, Costas E, Rebordosa X, OrtegaMora LM. Influence of age and purpose for testing on the cut-off selection of serological methods in bovine neosporosis. Vet Res. 2003; 34(3):341-52.

13. Lindsay DS, Dubey JP. Immunohistochemical diagnosis of Neospora caninum in tissue sections. Am J Vet Res. 1989;50(11):1981-3.

14. Dubey JP, Schares G. Diagnosis of bovine neosporosis. Vet Parasitol. 2006; 140(1-2):1-34

15. Parida M, Sannarangaiah S, Dash PK, Rao PV, Morita K. Loop-mediated isothermal amplification (LAMP): a new generation of innovative gene amplification technique; perspectives in clinical diagnosis of infectious diseases. Rev Med Virol. 2008;18(6):407-21.

16. Mori Y, Kanda H, Notomi T. Loop-mediated isothermal amplification (LAMP): recent progress in research and development. J Infect Chemother. 2013; 19(3):404-11.

17. Notomi T, Okayama H, Masubuchi H, Yonekawa T, Watanabe K, Amino N, Hase T. Loop-mediated isothermal amplification of DNA. Nucleic Acids Res. 2000;28(12):E63.

18. Sotiriadou I, Karanis P. Evaluation of loop-mediated isothermal amplification for detection of Toxoplasma gondii in water samples and comparative findings by polymerase chain reaction and immunofluorescence test (IFT). Diagn Microbiol Infect Dis. 2008;62(4):357-65.

19. Qu D, Zhou H, Han J, Tao S, Zheng B, Chi N, et al. Development of reverse transcription loop-mediated isothermal amplification (RT-LAMP) as a diagnostic tool of Toxoplasma gondii in pork. Vet Parasitol. 2013;192(1-3):98-103.

20. Kong QM, Lu SH, Tong QB, Lou D, Chen R, Zheng B, et al. Loop-mediated isothermal amplification (LAMP): early detection of Toxoplasma gondii infection in mice. Parasit Vectors. 2012;5:2.

21. Lisulo M, Sugimoto C, Kajino K, Hayashida K, Mudenda M, Moonga L, et al. Determination of the prevalence of African trypanosome species in indigenous dogs of Mambwe district, eastern Zambia, by loopmediated isothermal amplification. Parasit Vectors. 2014;7:19.

22. Gomes J, Amaro A, Santos-Gomes G, da Fonseca Pereira I, Inácio J. Development and field trial of a Tams1-targeted isothermal DNA amplification (Tams1-lamp) assay for detection of Theileria annulata in cattle. Parasit Vectors. 2014;7(Suppl. 1):P5.

23. Alhassan A, Thekisoe OM, Yokoyama N, Inoue N, Motloang MY, Mbati PA, et al. Development of loop-mediated isothermal amplification (LAMP) method for diagnosis of equine piroplasmosis. Vet Parasitol. 2007;143(2):155-60

24. Sriworarat C, Phumee A, Mungthin M, Leelayoova S, Siriyasatien P. Development of loop-mediated isothermal amplification (LAMP) for simple detection of Leishmania infection. Parasit Vectors. 2015;8:591.

25. Gao C-h, Ding D, Wang J-y, Steverding D, Wang X, Yang Y-t, Shi F. Development of a LAMP assay for detection of Leishmania infantum infection in dogs using conjunctival swab samples. Parasit Vectors. 2015;8:370.

26. Ishigaki K, Noya M, Kagawa Y, Ike K, Orima H, Imai S. Detection of Neospora caninum-specific DNA from cerebrospinal fluid by polymerase chain reaction in a dog with confirmed Neosporosis. J Vet Med Sci. 2012;74(8):1051-5.
27. Nagamine K, Hase T, Notomi T. Accelerated reaction by loopmediated isothermal amplification using loop primers. Mol Cell Probes. 2002;16(3):223-9.

28. Muller N, Zimmermann V, Hentrich B, Gottstein B. Diagnosis of Neospora caninum and Toxoplasma gondii infection by PCR and DNA hybridization immunoassay. J Clin Microbiol. 1996;34(11):2850-2.

29. Luo J-g, J-w G, L-j T, X-y Q, Y-p J, Cui W, et al. Development of a loopmediated isothermal amplification assay for rapid detection of bovine parvovirus. J Virol Methods. 2013;191(2):155-61.

30. Karthik K, Rathore R, Thomas P, Arun TR, Viswas KN, Agarwal RK, et al. Loopmediated isothermal amplification (LAMP) test for specific and rapid detection of Brucella abortus in cattle. Vet Q. 2014;34(4):174-9.

31. NEB. Guidelines for PCR Optimization with Taq DNA Polymerase. 2017. https://www.neb.com/tools-and-resources/usage-guidelines/guidelines-forpcr-optimization-with-taq-dna-polymerase. Accessed 23 Sept 2017.

32. Li Y, Fan P, Zhou S, Zhang L. Loop-mediated isothermal amplification (LAMP): a novel rapid detection platform for pathogens. Microb Pathog. 2017;107:54-61.

33. Kramer MF, Coen DM. Enzymatic amplification of DNA by PCR: standard procedures and optimization. Current protocols in molecular biology. Hoboken: Wiley; 2001.

34. Lin $X$, Chen $Y$, Lu Y, Yan J. Application of a loop-mediated isothermal amplification method for the detection of pathogenic Leptospira. Diagn Microbiol Infect Dis. 2009;63(3):237-42.

35. Gonçalves DS, Cassimiro APA, de Oliveira CD, Rodrigues NB, Moreira LA. Wolbachia detection in insects through LAMP: loop-mediated isothermal amplification. Parasit Vectors. 2014;7(1):1-5.

36. Edgar RC. MUSCLE: a multiple sequence alignment method with reduced time and space complexity. BMC Bioinformatics. 2004;5:113.

37. Remmerbach TW, Brinckmann UG, Hemprich A, Chekol M, Kuhndel K, Liebert UG. PCR detection of human papillomavirus of the mucosa: comparison between MY09/11 and GP5+/6+ primer sets. J Clin Virol. 2004; 30(4):302-8

38. Reichel MP, Alejandra Ayanegui-Alcerreca M, Gondim LF, Ellis JT. What is the global economic impact of Neospora caninum in cattle - the billion dollar question. Int J Parasitol. 2013;43(2):133-42.

39. Payne S, Ellis J. Detection of Neospora caninum DNA by the polymerase chain reaction. Int J Parasitol. 1996;26(4):347-51.

40. Yamage $M$, Flechtner $\mathrm{O}$, Gottstein B. Neospora caninum: specific oligonucleotide primers for the detection of brain "cyst" DNA of experimentally infected nude mice by the polymerase chain reaction (PCR). J Parasitol. 1996;82(2):272-9.

41. Baszler TV, Gay LJ, Long MT, Mathison BA. Detection by PCR of Neospora caninum in fetal tissues from spontaneous bovine abortions. J Clin Microbiol. 1999;37(12):4059-64.

42. Ellis JT, McMillan D, Ryce C, Payne S, Atkinson R, Harper PA. Development of a single tube nested polymerase chain reaction assay for the detection of Neospora caninum DNA. Int J Parasitol. 1999;29(10):1589-96.

43. Okeoma CM, Stowell KM, Williamson NB, Pomroy WE. Neospora caninum: quantification of DNA in the blood of naturally infected aborted and pregnant cows using real-time PCR. Exp Parasitol. 2005;110(1):48-55.

44. Collantes-Fernandez E, Alvarez-Garcia G, Perez-Perez V, Pereira-Bueno J, OrtegaMora LM. Characterization of pathology and parasite load in outbred and inbred mouse models of chronic Neospora caninum infection. J Parasitol. 2004; 90(3):579-83.

45. Matovu E, Kazibwe AJ, Mugasa CM, Ndungu JM, Njiru ZK. Towards Point-ofCare Diagnostic and Staging Tools for Human African Trypanosomiaisis. J Trop Med. 2012;2012:340538.

46. Zhang $\mathrm{H}$, Thekisoe OM, Aboge GO, Kyan H, Yamagishi J, Inoue N, et al. Toxoplasma gondii: sensitive and rapid detection of infection by loop-mediated isothermal amplification (LAMP) method. Exp Parasitol. 2009;122(1):47-50.

47. Lin GZ, Zheng FY, Zhou JZ, Gong XW, Wang GH, Cao XA, Qiu CQ. Loopmediated isothermal amplification assay targeting the omp25 gene for rapid detection of Brucella spp. Mol Cell Probes. 2011;25(2-3):126-9.

48. Acosta ICL, Centoducatte LDA, Soares HS, Marcili A, MFN G, Rossi Junior JL, Gennari SM. Occurrence of Neospora caninum and Toxoplasma gondii antibodies in dogs from rural properties surrounding a biological reserve, Espirito Santo, Brasil. Rev Bras Parasitol Vet. 2016;25:536-9.

49. Koloren Z, Kaya D, Avsar C. Detection of Cryptosporidium species in the sea and tap water samples of Black Sea, Turkey. J Parasitol. 2013;99(3):554-7.

50. Koloren Z, Sotiriadou I, Karanis P. Investigations and comparative detection of Cryptosporidium species by microscopy, nested PCR and LAMP in water 
supplies of Ordu, middle Black Sea, Turkey. Ann Trop Med Parasitol. 2011; 105(8):607-15.

51. Fernandez-Soto P, Gandasegui Arahuetes J, Sanchez Hernandez A, Lopez Aban J, Vicente Santiago B, Muro A. A loop-mediated isothermal amplification (LAMP) assay for early detection of Schistosoma mansoni in stool samples: a diagnostic approach in a murine model. PLoS Negl Trop Dis. 2014;8(9):e3126.

52. Bai Z, Shi L, Hu C, Chen X, Qi J, Ba X, et al. Development of a loop-mediated isothermal amplification assay for sensitive and rapid detection of Mycoplasma bovis. Afr J Biotechnol. 2011;10(57):12333-8.

53. Chen X, Wang X, Jin N, Zhou Y, Huang S, Miao Q, et al. Endpoint visual detection of three genetically modified Rice events by loop-mediated isothermal amplification. Int J Mol Sci. 2012;13(11):14421-33.

54. Deguo W, Guicheng H, Fugui W, Yonggang L, Ren D. Drawback of loopmediated isothermal amplification. Afr J Food Sci. 2007:2:83-6.

55. Njiru ZK. Loop-mediated isothermal amplification technology: towards point of care diagnostics. PLoS Negl Trop Dis. 2012;6(6):e1572.

56. Francois $\mathrm{P}$, Tangomo M, Hibbs J, Bonetti E-J, Boehme CC, Notomi T, et al. Robustness of a loop-mediated isothermal amplification reaction for diagnostic applications. FEMS Immunol Med Microbiol. 2011;62(1):41-8.

57. Nazir MM, Maqbool A, Akhtar M, Ayaz M, Ahmad AN, Ashraf K, et al. Neospora caninum prevalence in dogs raised under different living conditions. Vet Parasitol. 2014;204(3-4):364-8.

58. Wang S, Yao Z, Zhang N, Wang D, Ma J, Liu S, et al. Serological study of Neospora caninum infection in dogs in central China. Parasite. 2016;23:25.

59. Arunvipas P, Inpankaew T, Jittapalapong S. Risk factors of Neospora caninum infection in dogs and cats in dairy farms in Western Thailand. Trop Anim Health Prod. 2012;44(5):1117-21.

60. Gharekhani J, Tavoosidana G, Akbarein H. Serological study of Neospora caninum infection in dogs and cattle from west of Iran. Comp Clin Path. 2014;23(5):1203-7.

\section{Submit your next manuscript to BioMed Central and we will help you at every step:}

- We accept pre-submission inquiries

- Our selector tool helps you to find the most relevant journal

- We provide round the clock customer support

- Convenient online submission

- Thorough peer review

- Inclusion in PubMed and all major indexing services

- Maximum visibility for your research

Submit your manuscript at www.biomedcentral.com/submit 